\title{
PERANCANGAN PENGUKURAN PERGESERAN TANAH PADA SISTEM PERINGATAN DINI BENCANA TANAH LONGSOR
}

\author{
Muhammad Irsyad Reynaldi ${ }^{*}$, Aghus Sofwan, Sumardi \\ Departemen Teknik Elektro, Universitas Diponegoro \\ Jl. Prof. Sudharto, SH, Kampus UNDIP Tembalang, Semarang 50275, Indonesia \\ ${ }^{*}$ E-mail: irsyadreyn@gmail.com
}

\begin{abstract}
Abstrak
Tanah longsor merupakan salah satu bencana yang sering terjadi di Indonesia. Longsor dapat terjadi karena adanya beberapa faktor utama. Salah satu faktor tersbut adalah curah hujan yang tinggi dan kelembaban tanah. Selain itu ada beberapa faktor yang dapat diperhitungkan yang dapat menyebabkan bencana longsor. Dibutuhkan suatu sistem yang dapat mengakuisisi data data dilapangan agar dapat memprediksi terjadinya bencana longsor. Pada penelitian ini dibuatlah perancangan 3 buah prorotipe akusisi data dengan 4 parameter penyebab terjadinya tanah longsor. 4 parameter itu berupa kemiringan lereng yang dapat diukur dengan sensor MPU 6050, curah hujan yang diukur dengan sensor tipping bucket dengan reed switch, kadar air dengan 2 sensor kelembaban FC-28, dan getaran tanah yang diukur dengan sensor 801s. Sistem ini pun dilengkapi dengan proses pengambilan data ataupun log data secara realtime dengan SD Card dalam proses secara langsung dan pengiriman via server mealalui SIM900. Untuk indikasi alarm digunakan SX1278. Perancangan sistem ini berdasarkan hasil pembacaan 4 parameter ynag diukur. Dari hasil pengujian sensor didapatkan hasil pembacaan nilai setiap masing masing sensor dengan error 0.165 untuk sensor MPU6050, 0 untuk sensor tipping bucket, 0 pada sensor 801S, dan 0.39 dan 0.710 untuk 2 sensor kelembaban FC-28.
\end{abstract}

Kata kunci: Node sensor, Tanah longsor

\begin{abstract}
Landslide is one of the most frequent in Indonesia. Landslides can occur due to several major factors. One of these factors is $H I G H$ rainfall and soil moisture. In addition, there are several factors that can be taken into account that can cause landslide disaster. It takes a system that can acquire data field in order to predict the occurrence of landslide disaster. In this study made the design of 3 pieces of data acquisition prototype with 4 parameters causes the occurrence of landslides. The 4 parameters are slope measurements that can be measured with MPU 6050 sensor, rainfall measured used tipping bucket with reed switch, moisture content with 2 FC- 28 humidity sensors, and ground Vibration as measured by $801 \mathrm{~s}$ sensor. This system is also equipped with the process of data retrieval or log data in realtime with SD Card in the process directly and delivery via the server via SIM900. For alarm indication use SX1278. The design of this system based on the reading of 4 parameters ynag measured. From the sensor test results obtained readings value of each each sensor with error 0.165 for sensor MPU6050, 0 for sensor tipping bucket, 0 on 801S sensor, and 0.39 and 0.710 for 2 FC28 humidity sensor
\end{abstract}

Keywords : Node Sensor, Landslides.

\section{Pendahuluan}

Indonesia merupakan negara dengan tingkat bencana alam yang cukup tinggi. Salah satu bencana yang banyak terjadi di Indonesia adalah ta`nah longsor. Tanah longsor merupakan deskripsi dari suatu pergerakan meluncur dari tanah, bebatuan, dan material-material organik yang terdapat pada tebing yang diakibatkan oleh grafitasi dan struktur tanah yang dapat mempengaruhi pergerakan tanah tersebut. [1]. Menurut data informasi bencana Indonesia yang dikeluarkan oleh BNPB, pada tahun 2017 hingga
2018 telah terjadi sebanyak 3996 kejadian bencana meliputi bencana alam dan bencana non alam. Dari jumlah kejadian bencana yang terjadi terdapat 1116 kejadian tanah longsor yang telah terjadi di Indonesia sepanjang tahung 2017 hingga 2018 [2].

Longsor terjadi karena kondisi lereng yang tidak stabil, sehingga material / batuan di atas lereng kemudian bergerak menurun. Ketidakstabilan lereng dapat disebabkan oleh beberapa faktor, yang utama adalah penjenuhan material oleh air (hujan). Terdapat dua faktor yang dapat mempengaruhi terjadinya tanah longsor, yaitu 
faktor alam dan faktor aktivitas manusia. Faktor alam yang dapat memicu terjadinya tanah longsor adalah kandungan air, aktifitas seismik, dan aktifitas vulkanis. Pengaruh dari faktor-faktor tersebut dapat bermacam-macam tergantung dari faktor kemiringan dari tebing, morfologi dari tanah, tipe tanah, kondisi geologi tanah, dan ada atau tidaknya bangunan[3][4]. Faktor-faktor penyebab dan pemicu ini menjadi parameter dasar untuk menganalisa suatu kejadian tanah longsor.

Tanah longsor merupakan bencana yang terjadi secara tibatiba sehingga menelan banyak korban. Minimnya sistem peringatan mengakibatkan munculnya korban jiwa. Untuk itu diperlukan suatu alat pendeteksi longsor yang dapat mengidentifikasi berbagai parameter yang dapat menyebabkan bencana tanah longsor secara real time sehingga dapat menjadi peringatan awal terjadinya tanah longsor.

Pada penelitian sebelumnya telah dikembangkan suatu sistem peringatan dini untuk tanah longsor menggunakan data dari satelit dan database kondisi geospasial. Selain itu ada penelitian menganalisa data-data yang diperoleh dari satelit berupa monitoring curah hujan yang kemudian akan menghasilkan suatu prediksi terjadinya tanah longsor[5][6].

Pada penelitian ini dirancang 3 buah sensor node yang saling berhubungan melalui Jaringan Sensor Nirkabel yang memberikan keuntungan dalam pengukuran data di lapangan dan membuat sistem peringatan longsor lebih efektif. Alasan utama dalam penggunaan JSN adalah fleksibilitas pengiriman, komunikasi jarak jauh kan bersifat real time.

Sensor node ini memiliki 4 parameter utama, yaitu pendeteksian curah hujan, kadar air dalam tanah, kemiringan, dan getaran tanah. Dari 4 parameter tersebut diwakilkan oleh 5 sensor. Sensor FC-28 berjumlah 2 buah untuk kelembaban, sensor $801 \mathrm{~S}$ untuk getaran, MPU untuk kemirinan, dan reed switch untuk curah hujan.

\section{Metode}

Pada penelitian ini dirancang sensor node yang mendeteksi 4 parameter utama yang menyebabkan longsor. Paramater yang dideteksi adalah curah hujan, kelembaban, kemiringan dan getaran tanah. Untuk sensor yang digunakan akan mendeteksi parameter yang dibutuhkan. Sensor MPU 6050 digunakan sebagai pendeteksi kemiringan, sensor FC-28 digunakan sebagai sensor kelembaban, Tipping bucket dengan reed switch mendeteksi curah hujan di lingkungan alat dan sensor $801 \mathrm{~s}$ sebagai pembaca getaran tanah. Kemudia data dari 4 parameter tersebut akan tersimpan di data logger pad SD Card. Untuk serial komunikasi ,penelitian ini menggunakan SIM900 berbasis GPRS yang akan dikirim menjuju database
Pada penelitian ini dirancang sebuah sensor node yang dapat mendeteksi 3 paramater yang dapat menyebabkan terjadinya longsor. Parameter tersebut adalah kemiringan yang diukur dengan sensor MPU6050, Curah hujan dengan sensor hujan tipping bucket dan kadar air dalam tanah dengan sensor kelembaban tanah. Data ketiga parameter akan dikirim melalui modul GSM SIM900A ke dalam database yang nantinya akan ditampilkan dalam bentuk website. Selain itu pada penelitian ini dirancang sistem pendukung keputusan dengan jaringan saraf tiruan. Ini bertujuan untuk memprediksi kemungkinan awal terkait kondisi dini apakah status daerah terpasang alat aman, siaga atau bahaya. Arsitektur sistem keseluruhan pada penelitian ini seperti Gambar 1.

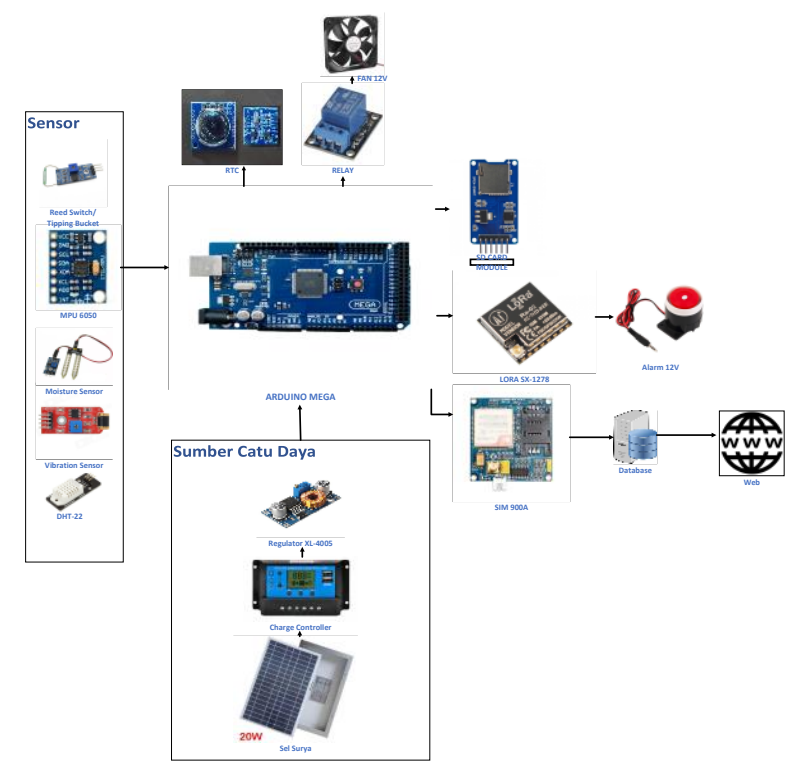

Gambar 1. Arsitektur Keseluruhan Alat

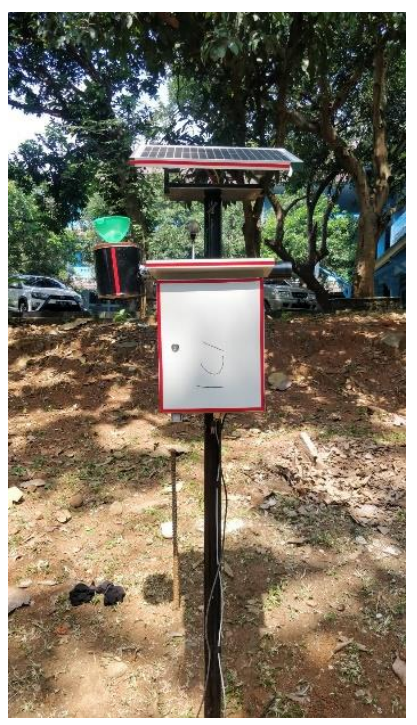

Gambar 2. Sensor Node Pendeteksi Longsor dini 


\subsection{Perancangan Perangkat Keras 2.1.1. Rangkaian Mikrokontroler Sensor Node}

Rancangan mikrokontroler sensor node pendeteksi longsor ini dapat dilihat pada Gambar 3. Rancangan perangkat keras ini terdiri atas mikrokontroller Arduino Mega2560, catu daya dari panel surya, sensor MPU6050, sensor kelembaban tanah, sensor curah hujan tipping bucket, regulator XL4005 dan modul SIM900A.

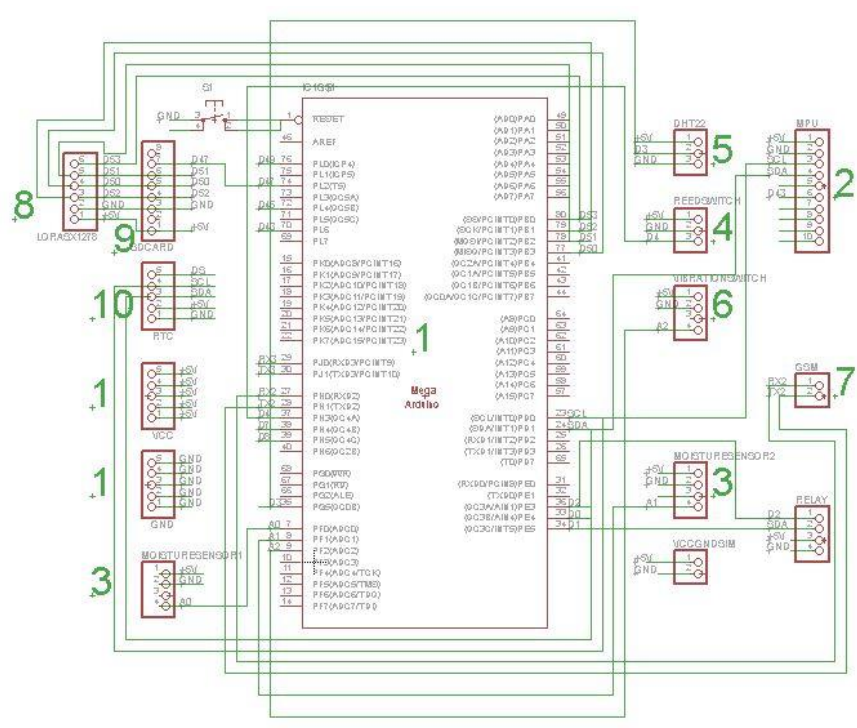

Gambar 3. Rangkaian Mikrokontroller Sensor Node

1. Arduino Mega sebagai pusat pengendalian dan pengolah data pada sensor node ini yang dapat diprogram dengan Arduino IDE

2. Sensor MPU6050 berfungsi untuk mengukur perubahan kemiringan lereng yang menggunakan komunikasi I2C(SCL\&SDA). Pin yang digunakan untuk menghubungkan sensor dengan mikrokontroller adalah pin 20(SDA) 21(SCL) dan 43(AD0) untuk menyesuaikan address MPU. Pada penelitian ini, sudut orientasi yang digunakan adalah sudut pitch[7].

3. Sensor Kelembaban tanah berfungsi untuk mengukur kadar air dalam tanah. Keluaran sensor ini berupa analog yang telah dikalibrasi sehingga satuannya dalam bentuk persen. Pin analog yang digunakan adalah pin A0 dan A1, untuk penggunaan 2 sensor yang memiliki perbedaan kedalaman.

4. Sensor curah hujan tipping bucket berfungsi untuk mengukur curah hujan menggunakan fungsi external interupt pada mikrokontroler. Pin interrupt yang digunakan adalah pin 5.

5. Sensor DHT-22 yang berfungsi sebagai pendeteksi kelembaban dan suhu pada sistem untuk mencegah overheat. Pin yang dikgunakan merupakan digital yaitu pin 4 .

6. Sensor Vibration 801S menggunakan pin analog A3 untuk mengukur besaran getaran tanah.

7. Modul SIM900A adalah modul GSM berfungsi untuk mengirimkan data sensor ke website menggunakan komunikasi serial. Arduino mega memiliki 3 fasilitas komunikasi serial. Pada penelitian ini modul GSM dihubungkan ke serial2 dimana pin RX modul dihubungkan dengan pin 17(TX) mikrokontroler dan pin TX modul dihubungkan dengan pin 16(RX) mikrokontroler[8].

8. Modul LORA SX-1278 adalah modul komunikasi radio yang menggunakan frekuensi $410-510 \mathrm{MHz}$ yang memiliki kapabilitas jangkauan jauh menggunakan komunikasi SPI pada pin 50(MISO), 51(MOSI), 52(SCK), dan SS(53)[9].

9. Modul SD Card berfungsi sebagai penyimpan dan membaca data logger dari sistem. Modul ini menggunakan komunikasi SPI pada 50(MISO), 51(MOSI), 52(SCK), dan SS(47).

10. Modul RTC (Real Time Clock) DS-1307 adalah modul yang berfungsi sebagai jam elektronik yang menghitung waktu sistem dan menjaga dta waktu tersebut secara real time. Modul ini menggunakan komunikasi I2C pada pin pin 20(SDA) dan 21(SCL).

11. Catu daya berasal dari panel surya yang terhubung ke aki dan solar power controller

12. Regulator XL4005 adalah penurun tegangan dari $12 \mathrm{~V}$ ke $5 \mathrm{~V}$.

\subsubsection{Rangkaian Catu Daya}

Perancangan rangkaian catu daya yang digunakan terdiri dari panel surya, solar power controller, aki kering, dan regulator penurun tegangan XL4005 seperti pada Gambar 4. Panel surya berfungsi sebagai sumber energi utama dengan kapasitas $20 \mathrm{wp}$. Tegangan keluaran panel surya berkisar diantara 12-20 V yang dihubungkan ke solar power controller. Solar power controller memiliki 3 sambungan. sambungan pertama dari panel surya yang menerima daya dari panel surya. Sambungan yang kedua terhubung ke aki kering $12.7 \mathrm{~V} 7.2 \mathrm{AH}$.

Sambungan ketiga terhubung ke beban. Beban disini adalah sistem sensor node yang membutuhkan tegangan kerja 5V. Sedangkan solar power controller memiliki keluaran sekitar 12V. Sehingga dibutuhkan penurun tegangan dengan regulator XL4005 yang memiliki kemampuan dalam rentang $4 \mathrm{~V}-38 \mathrm{~V}$. 


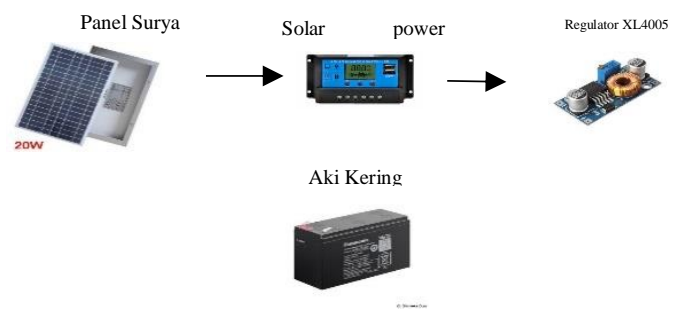

Gambar 4. Rangkaian Catu Daya

\subsubsection{Perancangan Perangkat Lunak}

Perancangan perangkat lunak pada penelitian ini menggunakan software Arduino IDE Pada komputer dengan menggunakan bahasa $\mathrm{C}$. Untuk perancangannya dapat dilihat pada Gambar 5.

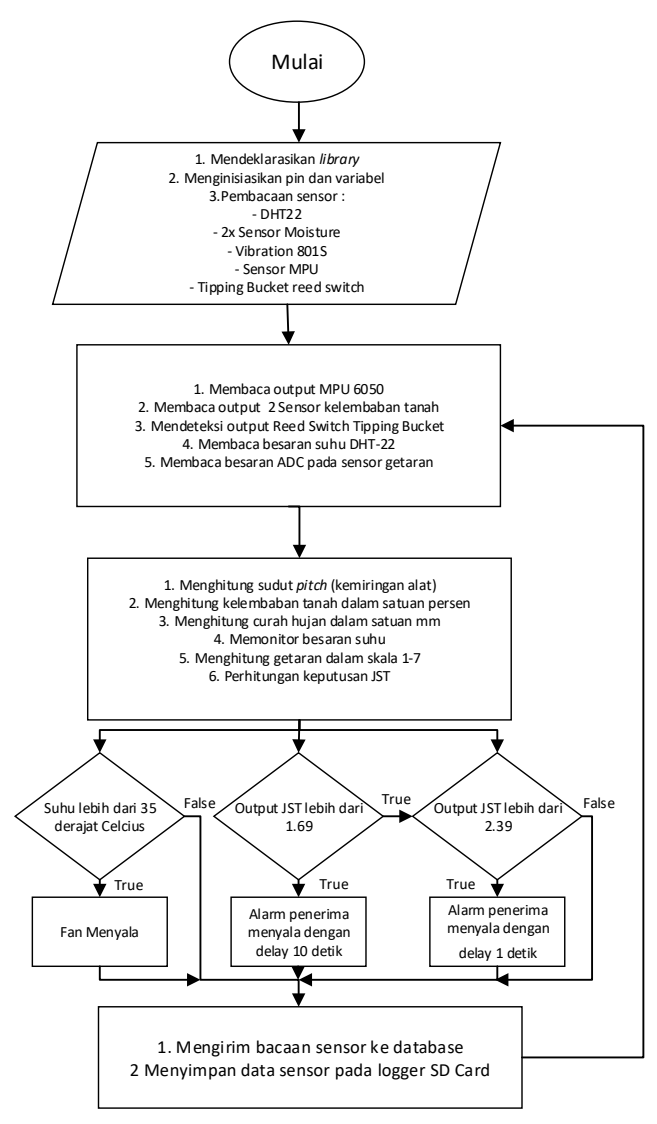

Gambar 5. Alir Diagram Perancangan Perangkat Lunak

Perancangan alat dimulai dengan pembuatan software pada Arduino IDE sebagai wadah dalam memuat program yang dibutuhkan dalam pemrosesan alat ini. Inisiasi dilakukan dengan memasukkan library tiap komponen yang terdiri dari Sensor 801S, DHT-22, 2 FC-28, MPU6050, dan reed switch. Untuk komponen komunikasi diinisiasikan module Lora SX1278, dan SIM900. Untuk komponen lainnya terdiri dari RTC,relay dan Fan. Setelah inisiasi pada
void(Setup), dilakukan perintah berulang pada Arduino di void(loop). Dimana pada perulangan ini dilakukan pembacaan sensor yang digunakan, kemudian diubah dalam bentuk parameter masing masing sensor. Setelah itu diambil keputusan apakah nilai nilai sensor tersebut memenuhi parameter bencana longsor melalui JST. Kemudian alat akan mengirimkan inidkasi alarm menuju receiver. Pada setiap pembacaan dilakukan penyimpan pad a server dan SD Card.

\section{Hasil dan Analisis \\ 3.1. Pengujan Parameter Kemiringan}

Pengujian sudut kemiringan lerengan memiliki rentangang dari $0-45^{\circ}$. Hal ini mengaju pada ketentuan kemiringan lerengan yang mana satuan yang digunakan adalah persen. Nilai $100 \%$ dalam kemiringan mewakili sudut $45^{\circ}$. Pada pengujian ini dilakukan variasi pengambilan data dari sudut $0 \%, 20 \%, 60 \%, 80 \%$ dan $100 \%$. Alat ukur yang dijadikan nilai referensi adalah aplikasi android "inclinometer" yang dapat mengukur kemiringan dalam $\%$. Pengambilan data diambil selama 10 menit dan selama 5 menit mengambil data yang akan dimasukkan kelaporan, dikarenakan respon MPU yang lambat. Pengambilan data memiliki waktu tunda selama 10 detik. Sehingga dapat dilihat nilai pengambilan data pada tabel 1

Tabel 1. Hasil Pengujian Kemiringan

\begin{tabular}{cccc}
\hline No & $\begin{array}{c}\text { Referensi Tingkat } \\
\text { Kemiringan (\%) }\end{array}$ & $\begin{array}{c}\text { Tingkat kemiringan } \\
\text { Objek }(\%)\end{array}$ & $\begin{array}{c}\text { Error } \\
(\%)\end{array}$ \\
\hline 1 & 0 & 0.192 & 0.192 \\
2 & 20 & 19.99 & 0.001 \\
3 & 40 & 39.98 & 0.002 \\
4 & 60 & 59.8 & 0.2 \\
5 & 80 & 80.23 & 0.23 \\
6 & 100 & 99.63 & 0.37 \\
\hline
\end{tabular}

Pada Tabel 1 diperlihatkan error rata-rata dari setiap pengujian pada waktu yang telah ditentukan. Rata-rata nilai error pada pada variasi kemiringan $0 \%, 25 \%, 50 \%$, $75 \%$, dan $100 \%$ masing-masing adalah $0,17,0,33,0,07$, 0,49 , dan 0,70 . Nilai error rata-rata tertinggi terdapat pada pengujian kemiringan $100 \%$ dan nilai error rata-rata terendah ada pada pengujian kemiringan 50\%. Untuk pengujian sensor ini memiliki nilai error 0.165833

\subsection{Pengujian Parameter Kadar Air dalam Tanah}

Pengujian nilai keluaran sensor kelembaban tanah dilakukan dengan menggunakan 2 sensor FC-28 dengan nilai variasi dari $0 \%$ - 90\%. Pengambilan data dilakukan selama 5 menit. Hasil pengambilan dapat dilihat pada tabel 2 dan tabel 3.

Dari tabel 2 diperlihatkan error rata rata sensor kelembaban 1 dari setiap pengujian berdasarkan alat kalibrasi dan besaran takaran air. Terlihat ahwa rata rata nilai error pada variasi kelembaban tanah 0\%, 10\%, 20\%, 
$30 \%, 40 \%, 50 \%, 60 \%, 70 \&, 80 \%$, dan $90 \%$ masing masing adalah $0.648,0.1787,0.244,0.204,0.036,0.444,0.387$, $0.214,0.195$, dan 1.432 Nilai error terbesar terlihat pada kelembaban tanah $90 \%$ sebesar 1.432 dan rata rata terkecil pada $40 \%$.sebesar 0.026 .

Tabel 2. Hasil Pengujian Sensor Kelembaban Tanah 1

\begin{tabular}{ccccccc}
\hline No & $\begin{array}{c}\text { Mtan } \\
\text { ah }\end{array}$ & $\begin{array}{c}\text { M } \\
\text { tanah } \\
\text { +Air }\end{array}$ & $\begin{array}{c}\% \\
\text { Hitung }\end{array}$ & $\begin{array}{c}\text { Alat } \\
\text { Kalibra } \\
\text { si }\end{array}$ & $\begin{array}{c}\% \\
\text { Sensor }\end{array}$ & Error \\
\hline 1 & 150 & 150 & $0 \%$ & $0 \%$ & 0.648 & 0.648 \\
2 & 150 & 165 & $10 \%$ & $10 \%$ & 9.8313 & 0.1787 \\
3 & 150 & 180 & $20 \%$ & $20 \%$ & 19.766 & 0.244 \\
4 & 150 & 195 & $30 \%$ & $30 \%$ & 29.796 & 0.204 \\
5 & 150 & 210 & $40 \%$ & $40 \%$ & 40.026 & 0.026 \\
6 & 150 & 225 & $50 \%$ & $50 \%$ & 49.556 & 0.444 \\
7 & 150 & 240 & $60 \%$ & $60 \%$ & 59.663 & 0.387 \\
8 & 150 & 255 & $70 \%$ & $70 \%$ & 70.214 & 0.214 \\
9 & 150 & 270 & $80 \%$ & $80 \%$ & 80.195 & 0.195 \\
10 & 150 & 285 & $90 \%$ & $90 \%$ & 88.568 & 1.432 \\
& & & & & & \\
& & & & & Rata & \\
& & & & & Rata & \\
& & & & & & \\
\end{tabular}

Tabel 3. Hasil Pengujian Sensor Kelembaban Tanah 2

\begin{tabular}{ccccccc}
\hline No & Mtanah & $\begin{array}{c}\text { M } \\
\text { tanah } \\
\text { +Air }\end{array}$ & $\begin{array}{c}\text { \% } \\
\text { Hitung }\end{array}$ & $\begin{array}{c}\text { Alat } \\
\text { Kalibra } \\
\text { si }\end{array}$ & $\begin{array}{c}\% \\
\text { Sensor }\end{array}$ & Error \\
\hline 1 & 150 & 150 & $0 \%$ & $0 \%$ & 0.657 & 0.657 \\
2 & 150 & 165 & $10 \%$ & $10 \%$ & 9.4335 & 0.5765 \\
3 & 150 & 180 & $20 \%$ & $20 \%$ & 19.446 & 0.56 \\
4 & 150 & 195 & $30 \%$ & $30 \%$ & 29.478 & 0.522 \\
5 & 150 & 210 & $40 \%$ & $40 \%$ & 41.368 & 1.368 \\
6 & 150 & 225 & $50 \%$ & $50 \%$ & 48.947 & 1,053 \\
7 & 150 & 240 & $60 \%$ & $60 \%$ & 59.319 & 0.681 \\
8 & 150 & 255 & $70 \%$ & $70 \%$ & 68.88 & 0.1222 \\
9 & 150 & 270 & $80 \%$ & $80 \%$ & 80.414 & 0.414 \\
10 & 150 & 285 & $90 \%$ & $90 \%$ & 88.948 & 1.152 \\
& & & & & & \\
& & & & & Rata & \\
& & & & & Rata & \\
& & & & & & \\
\end{tabular}

Dari tabel 3 diperlihatkan error rata rata sensor kelembaban 2 dari setiap pengujian berdasarkan alat kalibrasi dan besaran takaran air. Terlihat ahwa rata rata nilai error pada variasi kelembaban tanah 0\%, 10\%, 20\%, $30 \%, 40 \%, 50 \%, 60 \%, 70 \&, 80 \%$, dan $90 \%$, masing masing adalah $0.657,0.5765,0.56,0.522,1.368,1.053$, $0.681,0.1222,0.414$, dan 1.152 . Nilai error terbesar terlihat pada kelembaban tanah $40 \%$ sebesar 1.368 dan rata rata terkecil pada $70 \%$.sebesar 0.1222 .

Terlihat dari kedua pembacaan sensor kelembaban hujan, error terbesar terletak pada sensor 2 sebesar 0.710 . Hal ini dapat terjadi dikarenakan kondisi alat yang kurang responsif dalam pembacaan nilai data.

\subsection{Pengujian Parameter Curah Hujan}

Pengujian sensor curah hujan tipping buckett dilakukan dengan memasukkan beberapa variasi volume air kedalam wadah sensor. Dalam hal ini, variasi yang dilakukan sebanyak 8 kali dari volume $15 \mathrm{ml}$ sampai dengan $120 \mathrm{ml}$ dengan penambahan $15 \mathrm{ml}$ tiap percobaan.

Tabel 4. Hasil Pengujian Jumlah Tick Sensor Hujan Tipping Bucket

\begin{tabular}{ccccc}
\hline No. & $\begin{array}{c}\text { Volume } \\
\text { Air }(\mathrm{ml})\end{array}$ & $\begin{array}{c}\text { Jumlah } \\
\text { Tick } \\
\text { (teori) }\end{array}$ & $\begin{array}{c}\text { Jumlah } \\
\text { Tick } \\
\text { (pengamatan) }\end{array}$ & Error \\
\hline 1 & 60 & 4 & 4 & 0 \\
2 & 120 & 8 & 8 & 0 \\
3 & 150 & 10 & 10 & 0 \\
4 & 225 & 15 & 15 & 0 \\
\hline
\end{tabular}

Tabel 5. Hasil Pengujian Jumlah ml air Sensor Hujan Tipping Bucket

\begin{tabular}{cccc}
\hline No. & $\begin{array}{c}\text { Terbaca } \\
(\mathrm{ml})\end{array}$ & $\begin{array}{c}\text { Perhitungan } \\
(\mathrm{ml})\end{array}$ & $\begin{array}{c}\text { Errror } \\
(\mathrm{ml})\end{array}$ \\
\hline 1 & 60 & 60 & 0 \\
2 & 120 & 120 & 0 \\
3 & 150 & 150 & 0 \\
4 & 225 & 225 & 0 \\
\hline
\end{tabular}

Dari Tabel 4 dan Tabel 5 dapat dilihat bahwa jumlah tick pada sensor sudah sesuai dengan teori dan pengamtan sehingga didapatkan bacaan error sama dengan nol. Untuk hasil perhitungan besaran air sama dengan hasil terbaca . Nilai error terbaca sama dengan nol.

\subsection{Pengujian Sensor Getaran}

Pengujian sensor getaran $801 \mathrm{~S}$ dengan basis analog 10 bit yang berbanding dilakukan dengan melakukan variasi getaran yang dibandingkan dengna kalibrasi alat melalui aplikasi handphone android "Vibrometer". Variasi yang dilakukan dimulai dengan skala 0 hingga 7.

Tabel 6. Hasil Pengujian Sensor Getaran 801S

\begin{tabular}{ccccc}
\hline No. & $\begin{array}{c}\text { Getaran } \\
\text { (Skala) }\end{array}$ & $\begin{array}{c}\text { Alat } \\
\text { Kalibrasi }\end{array}$ & Besaran getaran & Error \\
\hline 1 & 1 & 1 & 1 & 0 \\
2 & 2 & 2 & 2 & 0 \\
3 & 3 & 3 & 3 & 0 \\
4 & 4 & 4 & 4 & 0 \\
5 & 5 & 5 & 5 & 0 \\
6 & 6 & 6 & 6 & 0 \\
7 & 7 & 7 & 7 & 0 \\
\hline
\end{tabular}

Dari Tabel 6 dapat dilihat bahwa besaran getaran pada sensor sudah sesuai dengan teori dan alat kalibrasi sehingga didapatkan bacaan error sama dengan nol.

\subsection{Pengujian GSM SIM900}

Pengujian SIM900 menggunakan provider telkomsel dilakukan pada perangkat sensor node dengan pengujian mengirim data menggunakan program Arduino IDE melalui serial TX RX . Berikut tampilan pengiriman dan penerimaan data dari SIM900 menuju server. 


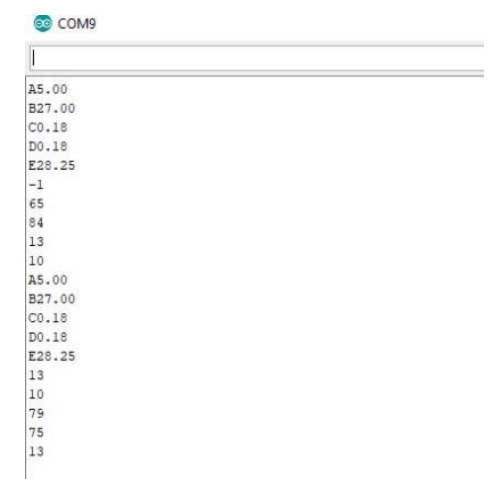

Gambar 6. Hasil Pengujian pengiriman data melalui SIM900

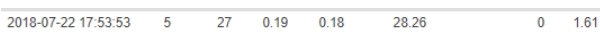

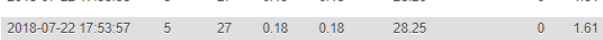

\section{Gambar 7. Hasil Pengujian penerimaan data pada server}

Terlihat pada pengujian SIM900 pengiriman dari Arduino IDE menuju server pada Gambar 6 dan Gambar 7 menunjukkan hasil yang sesuai dimana data berhasil diterima pada server.

Pengujian Lora SX1278 dilakukan dilakukan pada perangkat penerima dan pengirim . Penerima dilakukan pada alat perangkat node sedangkan penerima di indicator alarm. Frekuensi radio yang digunakan yaitu $433 \mathrm{mHz}$. Tampilan data pengirim dan penerima ditampilkan pada Gambar 8 dan Gambar 9 sebagai berikut :

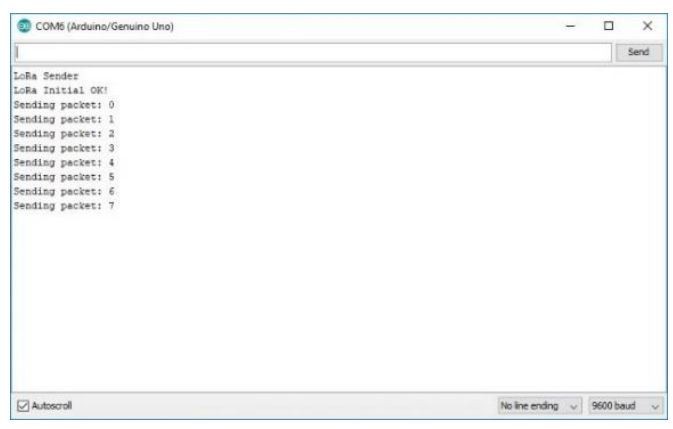

Gambar 8. Hasil Pengujian Lora SX1278 pada perangkat pengirim

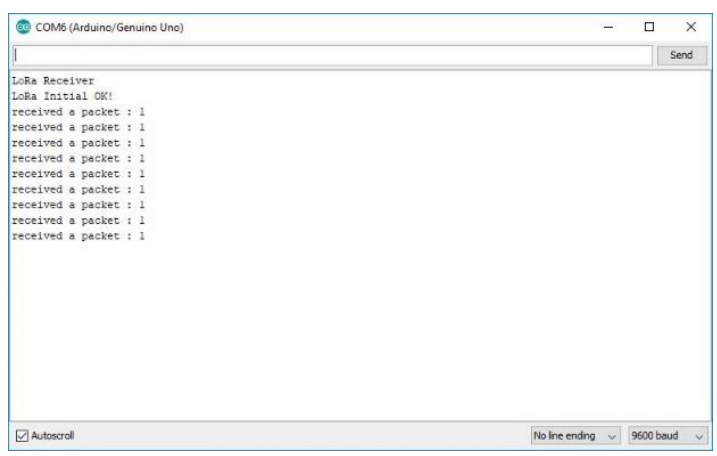

Gambar 9. Hasil Pengujian Lora SX1278 pada perangkat penerima

Terlihat pada pengujian Lora SX1278 penerima dan perangkat berhasil mengirim dan menerima data. Untuk pengujian pada pengirim, alat mengirim perintah " 1 " untuk mengaktifkan alarm pada perangkat penerima.

\section{Kesimpulan}

Ketiga sensor node pada wireless sensor network untuk 4 parameter penyebab terjadinya tanah longsor telah dirancang sesuai dengan spesifikasi. Untuk pengujian pada penelitian ini hanya diuji pada 1 alat dan kedua alat yang lain sudah terverivikasi hasilnya sesuai dengan referensi Pada pengujian param parameter kemiringan dengan sensor MPU6050 pada sudut orientasi pitch didapat error rata-rata saat pengujian kemiringan 0\%, 20\%, 40\%, $60 \%, 80 \%$, dan $100 \%$ masing-masing adalah $0.192,0.001$, $0.002,0.2,0.23$ dan 0.37 . Untuk nilai error secara keseluruhan pada pengujian MPU6050 sebesar 0.165. 3. Pada pengujian parameter kadar air dalam tanah dengan sensor kelembaban tanah didapat hasil keluaran sensor kelembaban 1 memiliki rata-rata error terbesar pada presentase kelembaban tanah $90 \%$ dengan rata-rata error sebesar 1.432 dan terkecil pada presentase kelembaban tanah $40 \%$ dengan rata-rata error sebesar 0.026. Pada sensor kelembaban 2 memiliki rata-rata error terbesar pada presentase kelembaban tanah $90 \%$ dengan rata-rata error sebesar pada 1.152 dan terkecil pada $70 \%$ dengan rata-rata error terbesar sebesar 0.122. Untuk rata rata error keseluruhan sensor kelembaban 1 memiliki nilai 0.39 dan sensor kelembaban 20.710 . Untuk pengujian parameter curah hujan dengan menggunakan sensor hujan tipping bucket didapat nilai error sama dengan 0. Untuk komunikasi SIM900 telah berhasil mengirim data dari sensor node menuju server dengan waktu delay 4 detik. Kemudian Lora SX1278 telah berhasil mengirim indikasi alarm dari sensor node menuju alat receiver. 


\section{Referensi}

[1]. R. Dlfference and K. Nakamura, "Speclal Reference," no. September, pp. 93-103, 1994.

[2]. BNPB, "Data dan Informasi Bencana Indonesia - BNPB."

[3]. Peraturan Menteri Pekerjaan Umum No.22/PRT/M/2007. Jakarta, 2007.

[4]. H. C. Hardiyatmo, Tanah Longsor \& Erosi. Yogyakarta: Gajah Mada University Press, 2006.

[5]. M. Ridho and A. Sofwan, "Perancangan Prototipe Sensor Node pada Wireless Sensor Network Menggunakan Jaringan Saraf Tiruan sebagai Pengambilan Keputusan pada Sistem Pendeteksi Dini Tanah Longsor."
[6]. T. Faisal, F. Gadjah, I. Dwikorita, and K. Gadjah, "Development of Landslide Monitoring and Early Warning System in Indonesia," 2nd Int. Work. Multimodal Sediment Disaster - Asian Cloud Netw. Disaster Res., no. Icl, pp. 481-484, 2008.

[7]. InvenSense, "MPU-6000 and MPU-6050 Register Map and Descriptions," vol. Rev 4, pp. 1-47, 2012.

[8]. "SIM900_Hardware Design_V2.00."

[9]. Semtech, "SX1276/77/78/79 Datasheet," no. March, p. $132,2015$. 